\title{
Pertunjukan Wayang Dalam Era Global
}

\author{
SOETARNO* \\ Jurusan Pedalangan, Fakultas Seni Pertunjukan, \\ Institut Seni Indonesia Surakarta
}

\begin{abstract}
Shadow Puppet Performances in Global Era. This article discusses the changes of shadow puppetry in relation to the changes of society in global era. Some relevant changes are in the fields of: (a) communication technology; (b) social systems; and (c) value systems. To anticipate these changes, puppet masters have also made some changes in their performances. The shadow puppet performances and society cannot stand alone but they have mutual interactions. Each of them may act as an object or as a subject. Thus, in transitional or developing society, the influences of social and shadow puppetry are mutual. Shadow puppet performances reveal social tendencies while society show influences on the development of shadow puppetry world.
\end{abstract}

Key words: wayang, perubahan sosial, era global.

\section{Pendahuluan}

Kehidupan masyarakat Indonesia pada abad XXI dengan tahap-tahap pembangunan yang telah dilakukan ternyata membawa permasalahan dalam segala aspek kehidupan. Salah satu masalah yang sangat menonjol adalah terjadinya perubahan sistem nilai, sedangkan nilai-nilai baru belum mantap fungsinya dalam mengarahkan kehidupan bangsa Indonesia. Dalam warisan budaya tradisional terjadi perongrongan sehingga menimbulkan ketidakpastian fundamental di bidang norma dan nilai. Oleh sebab itu masyarakat yang mengalami perubahan sosial yang cepat menyebabkan warganya akan kehilangan jati diri dan masyarakatnya dalam keadaan kebingungan.

Kemajuan teknologi komunikasi membuat jarak dunia semakin kecil dan kebudayaan-kebudayaan yang semula tumbuh dan berkembang di lingkungannya sendiri, sekarang terjadi percampuran dan silang budaya. Hal itu terjadi oleh karena pengaruh dari kebudayaan industri yang progresif berdasarkan kemajuan ilmu pengetahuan dan teknologi.

Kehidupan kesenian tidak luput dari pengaruh kebudayaan modern, dan tidak jarang bentukbentuk kesenian diciptakan untuk keperluan pasar. Artinya kesenian itu disajikan untuk pemenuhan kebutuhan praktis yang lebih mementingkan unsur hiburan dangkal. Hal itu juga terjadi dalam pertunjukan wayang kulit. Pertunjukan wayang sekarang cenderung mengikuti selera pasar dan pada hal-hal yang glamour, lekoh, gobyog, mlaha, dan mengabaikan nilai estetis. Dimaklumi bahwa para dalang mempunyai hak untuk mempertahankan hidupnya, namun demikian mereka juga perlu mengembangkan wawasan tentang seni yang positif, yaitu bahwa seni merupakan ekspresi estetis.

Pada tahun 1960-1990 para pengamat wayang dapat menemukan sebutan dalang seperti dalang apik, dalang wasis, dalang pinter, dan dalang sabet. Dalang apik, artinya dalang yang dalam penyajiannya selalu mengutamakan nilai estetis. Dalang wasis, adalah dalang yang dalam penampilannya mengutamakan unsur dramatiknya serta sanggit lakon; dalang pinter, adalah dalang yang penyajian pakelirannya selalu menyampaikan nilai-nilai spritual yang menyangkut ilmu kesempurnaan hidup; dan dalang sabet adalah dalang yang menampilkan ketrampilan gerak wayang yang sangat menonjol dalam penyajiannya. Tetapi seiring dengan perubahan sistem masyarakat yang terjadi serta perubahan sistem nilai akibat dari proses modernisasi, maka sekarang muncul berbagai sebutan dalang berdasarkan wujud penyajiannya

*Alamat korespondensi: ISI Surakarta, Jln. Ki Hajar Dewantara, Kentingan, Solo. Tlp. 08122657495.email: tarno_dea@yahoo. com 
misalnya dalang edan, dalang mbeling, dalang setan, dalang intelek, dalang komersial, dan sebagainya.

Wujud garapan pakeliran wayang sekarang ini pada umumnya menonjolkan sabet yang berlebihan, penyajian gending dolanan untuk pilihan pendengar serta humor yang vulgar dan porno. Umar Kayam (1981:141) berpendapat bahwa kesenian massa, termasuk wayang kulit, harus dikemas sebagai dagangan massa dan dijajakan serta disalurkan lewat pasaran massa tidak selalu harus muncul sebagai kesenian yang cethek atau instan, namun harus dapat diterima secara serius.

Fenomena yang terjadi dalam jagad pakeliran sekarang ini mengisaratkan adanya pergeseran cara pandang masyarakat baik para dalang maupun penonton dalam menyikapi pertunjukan wayang. Dampak dari pergeseran itu adalah terjadinya kekaburan nilai-nilai, yaitu nilai lama atau tradisional yang telah mapan mulai ditinggalkan. Sementara itu nilai-nilai baru belum mantap fungsinya bahkan belum ditemukan. Hal itu tercermin dalam setiap pertunjukan wayang kulit purwa Jawa masa kini. Permasalahan ini kiranya menarik dan penting untuk dikaji dan juga sebagai bahan pembicaraan yang mengarah pada perdebatan teoretis, praktis, dan filosofis.

\section{Perubahan Pakeliran Wayang}

Pada era reformasi, perubahan yang begitu cepat serta krisis ekonomi yang berkepanjangan, membuat beban hidup semakin berat. Dengan demikian kualitas kehidupan menurun drastis dan tidak menentu. Perubahan yang begitu cepat itu ternyata menambah tingkat kompleksitas masyarakat urban yang pada gilirannya harus bekerja untuk mempertahankan hidup, dan tidak jarang membuat keputusan yang cepat tanpa melalui perenungan yang dalam. Situasi yang demikian itu juga berdampak terhadap kesenian, khususnya pertunjukan wayang kulit Purwa Jawa.

Temuan hasil pengamatan di lapangan menunjukkan bahwa pertunjukan wayang kulit dewasa ini ada kecenderungan makin berkembang menjadi bentuk-bentuk hiburan dan sebagai komoditi dagangan. Ciri-ciri pertunjukan wayang yang dikemas untuk keperluan pasar antara lain bentuk penyajian pakelirannya lebih menekankan kemampuan komunikasi dari pada penghargaan kritis dari penonton. Sang dalang penyaji lebih suka memilih estetika resepsi atau estetika penonton daripada estetika kreasi yang berisi nilai moral universal, sedangkan keindahan pakeliran lebih cenderung pada kemampuan untuk memenuhi selera dan memadai permintaan massa dengan kebutuhan nyata publik.

Bentuk pakeliran lebih mementingkan aspek komunikasi dibanding dengan mempertahankan sastra pedalangannya. Terdapat kecenderungan dalam pakeliran digunakannya kata-kata seharihari, sedangkan kata-kata Kawi makin sedikit digunakan, hanya terdapat dalam cakepan suluk saja. Dengan demikian konvensi pentas sastra mulai ditinggalkan. Selain itu garapan tokoh-tokohnya dalam lakon yang disajikan menunjukkan gejala antihero dengan mempresentasikan tokoh-tokoh gambaran manusia biasa seperti tokoh: Limbuk, Cangik, Gareng, Petruk, Bagong, dsb., yang semuanya itu lebih ditekankan pada kehidupan profan dan lebih dekat dengan urusan sehari-hari.

Beberapa perubahan yang terjadi dalam jagad pedalangan, berhubungan dengan perubahan yang terjadi di masyarakat. Beberapa perubahan dalam kehidupan masyarakat yang relevan dengan perubahan dalam jagad pewayangan adalah: (a) perubahan teknologi komunikasi; (b) perubahan sistem sosial; dan (c) perubahan sistem nilai.

\section{Perubahan Teknologi Komunikasi}

Perkembangan teknologi komunikasi yang begitu cepat membawa implikasi yang sangat besar terhadap kehidupan kesenian termasuk pertunjukan wayang. Dengan hadirnya teknologi komunikasi dapat mengantarkan pertunjukan wayang di rumah-rumah penduduk ataupun melalui media audiovisual. Bahkan bentukbentuk kesenian yang lain dapat dinikmati lewat radio atau televisi seperti film, sinetron, kethoprak, musik pop, musik rock, dangdut, campursari, dan sebagainya. Perkembangan teknologi komunikasi selain membuat orang betah tinggal di rumah juga ternyata menawarkan berbagai macam pertunjukan sehingga membuat daya apresiasi seni masyarakat terhadap pertunjukan wayang semakin menurun.

Hubungan antara seni pewayangan dengan perkembangan teknologi komunikasi modern menurut budayawan Arswendo Atmowiloto adalah sebagai keju atau mentega yang mau tidak mau harus masuk ke dalam "nasi goreng" 
seni pewayangan. Memang disadari sepenuhnya bahwa teknologi komunikasi adalah sebagai simbol lain era baru, serta tidak jarang dimanfaatkan untuk mempromosikan pertunjukan wayang kepada masyarakat. Akan tetapi teknologi juga dimanfaatkan oleh dalang dalam menyajikan karya pakelirannya. Misalnya tata lampu dan tata suara telah menjadi unsur yang diperlukan untuk pertunjukan wayang.

Pemanfaatan teknologi dapat diamati pada pakeliran Manteb Soedarsono yang selalu menggunakan tata lampu pada adegan-adegan tertentu dan tata suara untuk mendukung peristiwaperistiwa yang ditampilkan. Tata lampu dan tata suara itu sekarang dimanfaatkan oleh beberapa dalang dalam penyajian pakeliran. Demikian pula akhir-akhir ini muncul berbagai eksperimen dalam wayang yang memanfaatkan teknologi seperti wayang multimedia, wayang sandosa, wayang elektronik dan sebagainya. Hal itu dilakukan oleh karena kompleksnya tuntutan global yang harus dihadapi oleh para dalang dalam menyikapi perubahan zaman. Pemanfaatan teknologi dalam pertunjukan wayang dapat menunaikan suatu paradoksi, yaitu terjadi suatu kemajuan tetapi di lain pihak juga terjadi kemunduran bilamana sang dalang tidak dapat memanfaatkan secara terpadu dan integral.

\section{Perubahan Sistem Sosial}

Sejak zaman Oerde Baru, berbagai teknologi komunikasi modern merambah seluruh pelosok Indonesia. Tidak hanya itu saja, peradaban modern juga mulai diterapkan masyarakat Indonesia seperti sistem perekonomian modern, sistem birokrasi dan administrasi modern, membangun negara yang demokratis (Kayam, 2001:385), dan lain sebagainya. Semenjak Indonesia memproklamirkan kemerdekaannya, sistem sosial semakin longgar dan tampak jelas. Seluruh lapisan masyarakat dapat mengenyam pendidikan dan mempunyai hak yang sama untuk tampil ke permukaan sistem sosial yang ada. Dalam situasi yang demikian itu dalam dunia kesenian terjadi tukar-menukar dan tular-menular nilai kesenian. Dalam dunia pewayangan tular-menular juga terjadi. Sebagai contoh, sabet wayang gaya wetanan yang pada tahun 1965 dianggap bermutu pasaran atau sabetan dhalang ndesa ternyata dapat menularkan pada pakeliran gaya keraton yang sekarang justru menjadi trend bagi setiap pakeliran wayang. Contoh sabetan wayang dewasa ini yang berkembang di masyarakat berasal dari sabetan dalang Gandabuwana dari Kedungbanteng yang ditiru oleh dalang Darman Gandadarsana dan selanjutnya diperkaya oleh Manteb Sudarsono yang mulai tenar tahun 1985. Gaya sabet Manteb Sudarsono itulah yang selanjutnya ditiru oleh para dalang yunior dan menjadi trend sabet wayang kulit dewasa ini.

Gaya sabet Manteb Sudarsono mengubah pertunjukan wayang yang semula lebih mementingkan catur, ginem, janturan dan pocapan seperti yang dilakukan dalang tenar sebelumnya seperti Pujasumarta dari Klaten, Wignyasutarna dari Surakarta, Nyatacarita dari Kartasura, Anom Suroto dari Surakarta dan Nartasabda dari Semarang. Semenjak muncul di tingkat nasional tahun 1986. Manteb Sudarsono mengubah jagad pedalangan menjadi pertunjukan yang lebih menekankan visual dalam bentuk gerak atau sabet wayang. Demikian pula sulukan gaya rakyat atau pedesaan dapat menularkan pada pakeliran gaya Surakarta. Hal itu dapat dicermati sulukan yang disajikan para dalang masa kini antara lain sulukan setelah jejer pertama di Astina dalam lakon Dewa Ruci oleh Manteb Soedarsono dan dalang lain yang menjadi pengamatan penulis.

Sistem kesenian kelas bawah yang bersifat spontan dan humoris juga menembus dalam jagad pedalangan. Pakeliran wayang pada tahun 1950-1960 dalam adegan tertentu misalnya pada adegan jejer masih nampak serius, regu, tetapi sejak munculnya dalang Nartasabda di tahun 1958an, adegan lucu sering terselip pada adegan yang sebenarnya serius. Adegan lucu pada setiap adegan pakeliran itu juga ditemui pada pertunjukan wayang dewasa ini baik pertunjukan wayang gaya Yogyakarta maupun Surakarta.

Percampuran gaya pakeliran sebelum tahun 1960, oleh para dalang dianggap merusak atau menjadi pantangan. Akan tetapi sejak tahun 1961, dalang Nartasabda memadukan garap pakeliran gaya Surakarta dengan gaya lain dengan cara memasukkan gara-gara gaya Yogyakarta. Tidak terbatas pada kedua gaya itu saja, gendinggending di luar Surakarta juga masuk dalam pakelirannya, misalnya gending Banyumasan, Pasundan, Semarangan, Jawa Timuran, dan sebagainya. Beberapa repertoar seperti gendhing 
Wandhali memadukan gending Jawa, Sunda dan Bali.

Dalam pertunjukan wayang kulit dewasa ini, percampuran gaya pakeliran dan percampuran garap karawitan merupakan sebuah gejala yang dianggap wajar, bahkan masuknya lawak dan penyanyiserta penggunaan instrumen non gamelan dalam pertunjukan wayang merupakan gejala yang dianggap biasa dan merupakan bagian integral dari suatu pertunjukan wayang kulit purwa masa kini. Dengan demikian dapat dikatakan bahwa bentuk-bentuk kesenian dan khususnya wayang kulit yang semula tumbuh dalam lingkungannya sendiri sekarang bercampur-aduk saling pengaruh mempengaruhi dengan kesenian-kesenian lain akibat pengaruh dari kebudayaan industri yang progresif berdasarkan kemajuan ilmu, teknologi, dan ekonomi. Bahkan pertunjukan wayang kulit dewasa ini cenderung dikemas sedemikian rupa menjadi seni kemasan atau kitsch. Kata kitsch secara etimologi dari kata verkitchen yang dalam bahasa Jerman berarti membuat murah. Kesenian kitsch pada umumnya disamakan dengan seni popular bahkan disebut sebagai selera rendah, dilawankan dengan kesenian tinggi, sebab kitsch mementingkan reproduksi, keuntungan secara ekonomis bahkan antiestetis.

\section{Perubahan Sistem Nilai}

Hadirnya peradaban Barat di Indonesia seperti administrasi modern, sistem komunikasi modern, birokrasi modern, serta perkembangan ilmu pengetahuan dan teknologi, mengakibatkan terjadinya perubahan yang mendasar yaitu perubahan sistem nilai. Perkembangan ilmu pengetahuan dan teknologi mengubah pemikiran masyarakat dari mistik-magis ke dunia empirik rasional. Hal yang demikian itu membawa kecenderungan masyarakat pada yang realistis dan sesuatu yang dapat dibuktikan. Kecenderungan masyarakat akan hal yang realistis itu nampaknya memberikan pengaruh pula terhadap pertunjukan wayang kulit. Ada kecenderungan penggunaan bahasa yang prosaik, lugas dalam janturan, pocapan atau dalam ginem. Sebagai contoh ginem antara tokoh Batara Guru dengan Semar dalam lakon Parikesit Jumeneng Nata berikut.

Guru: Kakang Semar kados pundi kok lajeng dukaduka
Semar: Dhisik janjine piye, aku tak kon mudhun menyang Ngarcapada dadi pamonge para satria. Dene kowe dadi ratu ana Kayangan, aku mung trima dadi pamong, la kok saiki kowe blenjani. Aku biyek rak wis janji satria sing tak emong kudu ketrima, e saiki satria sing tak emong kok lebur tumpur tanpa dadi.

Guru: Sing lebur tampur kuwi sapa.

Semar: Sing lebur tumpur kuwi Parikesit digung geni Yomani, iku geni neraka jahanam, saka gamane Dhayangsela. Cundhamanik kuwi gamane Batari Wilutama. Wilutama kuwi rak dhemenanmu ta?

Guru: Kakang Semar kuwi kok werna-werna.

Semar: Ah ora perlu ditutupi, hayo kapan ora gelem nguripake momonganku Parikesit iki titenana tak dublag gethuk lindri.

(Tristuti dalam Parikesit Jumeneng Nata)

(Guru: Kanda Semar bagaimana marah-marah

Semar: Dahulu sudah melakukan perjanjian, saya harus turun ke dunia untuk mendampingi para ksatria , sedangkan anda menjadi raja di kayangan dan saya menerima sebagai abdi / pamong, tetapi sekarang ingkar janji. Dahulu saya telah meminta bahwa semua ksatria yang bersama dengan Semar harus sukses, tetapi sekarang ia hancur.

Guru: Yang hancur itu siapa

Semar: Yang hancur itu Parikesit dimasukan ke api neraka karena senjatanya Danyangsela, yaitu Cundamanik senjatanya Wilutama. Batari Wilutama itu pacar gelap anda.

Guru: Kanda Semar itu macam-macam saja

Semar: Tidak perlu ditutupi, bilamana anda tidak menghidupkan Parikesit mulutmu akan saya beri gethuk lindri.

Contoh yang lain pada adegan Limbuk-Cangik dan adegan gara-gara sering disajikan gendhinggendhing atau lagu seperti Mijil Kethoprak, Kutut Manggung Candra Lukitan, Sinom Parijatha, bahkan gendhing non karawitan atau lagu campursari atau congdhut (keroncong ndhangdut) seperti lagu Caping Gunung, Nyidam Sari, Lingsir Wengi, Pepeling, Mung Sliramu, Popok Beruk Keli, Randho Kempling dan sebagainya.

Pada penyajian lagu-lagu pop campursari atau gendhing dolanan ada kecenderungan 
dalang memasukkan parikan yang diselesaikan oleh pesindhen. Tujuan dimasukkannya parikan adalah untuk membuat humor, tetapi celakanya bahwa humor yang dibuat lewat parikan itu pada umumnya berbau porno atau jorok atau keluar dari pakeliran.

Hal itu dapat dicermati pada lagu Caping Gunung dalam lakon Petruk Gembol yang diselingi parikan sebagi berikut.

Tuku kemanak weton Mediun

Bareng penak emoh mudhun

(membeli kemanak dari Madiun

setelah terasa nikmat tidak mau turun)

Tuku gethuk weton Semarang

Barange mlenuk, weruhe arang-arang

(membeli gethuk dari Semarang

barangnya menonjol, melihatnya jarang sekali)

Parikan yang agak berbau porno juga terdapat dalam lagu Caping Gunung pada lakon Wisanggeni Kridha sebagai berikut.

Menyang Demak tuku bulus

Lagi dibuka jebul wis klebus

(pergi ke Demak membeli kura-kura

sedang dibuka saja sudah basah)

Tuku Bulus regane setali

Yen wus klebus ndang dilapi

(membeli kura-kura seharga dua puluh lima sen bilamana telah basah segera dibersibkan)

Permainan kata-kata atau parikan tersebut di atas walaupun maknanya baik tetapi di kalangan khalayak penonton disambut dengan tertawa yang menggelikan dan ditangkap dengan asosiasi yang porno. Parikan dan cakepan yang berbau seks dan jorok juga dapat ditemui pada gendhing Kutut Manggung, cengkok Candra Lukitan, pada ndheg-ndhegan vokal sindhen dalam lakon Wahyu Mustika Jati seperti berikut.

Sindhen: E, manuké sing demung lemes

(E, burungnya yang main demung lemes)

Sindhen: E, manuké sing nyuting cilik

(E, burungnya (kelamin) kameramen kecil)

Cakepan yang sebenarnya adalah: E, manuké kutut, diplesetkan sehingga menimbulkan asosiasi yang jorok dan seronok, dan mempunyai makna yang berlainan dengan makna yang sebenarnya dalam Cakepan Kutut Manggung. Parikan diselasela lagu dolanan yang disampaikan oleh para pesindhen atau pelawak menjadi trend atau kebiasaaan dalam pertunjukan wayang purwa Jawa dewasa ini.

Kemajuan ilmu pengetahuan, teknologi, dan ekonomi, selain menumbuhkan orientasi masyarakat pendukung wayang kepada realitas, juga ada tuntutan akan efisiensi dan efektivitas. Modernisasi juga mengandung berbagai faktor yang menumbuhkan suatu sistem nilai tertentu, yakni unsur realisme, kompetisi, efisiensi, dan efektivitas, juga unsur kebaruan atau dinamika baru. Tuntutan akan hal-hal yang baru itu ditangkap oleh para dalang dalam menyikapi tuntutan masyarakat dan dieksploitasi dengan baik dalam pakeliran antara lain terdapat pada pembentukan alur cerita, garapan lakon, iringan karawitan, penggunaan bahasa, dan sebagainya. Menurut Adolph Tomars (1964), kehadiran sebuah kelas atau golongan masyarakat akan menghadirkan pula gaya dan bentuk seni yang khas, sesuai dengan selera estetis golongan tertentu. Berdasarkan kenyataan di lapangan dengan meminjam pemikiran Tomars, bentuk pertunjukan wayang kulit dewasa ini, ada kecenderungan makin berkembang menjadi bentuk-bentuk hiburan dan sebagai komoditi komersial. Ciri-ciri pakelirannya antara lain: (1) bentuk penyajiannya lebih menekankan kemampuan komunikasi ; (2) penyaji atau dalang lebih suka memilih estetika resepsi (estetika menurut selera penonton) ; (3) keindahan pakeliran wayang cenderung pada kemampuan untuk memenuhi selera dan memadahi permintaan massa yang bersifat hedonistik ;(4) ada kecenderungan penggunaan kata-kata sehari-hari (bahasa rakyat);(5) ada kecenderungan mempresentasikan tokoh-tokoh gambaran manusia biasa.

Pertunjukanwayangkulitdewasainitampaknya telah kandas dalam eksperimen pakeliran yang semakin lama semakin berupa permainan bentuk hura-hura. Bentuk sajian pakeliran yang demikian atau dalam bentuk kesenian materialistik dan hedonistik maka akan kehilangan makna hidup yang lebih dalam. Kehidupan pewayangan dan garap karawitan wayang bilamana terus-menerus seperti itu, para dalang dan pengrawitnya akan 
kehilangan arah dan hanya menghasilkan karya seni yang tidak berjiwa. Dengan demikian terjadi dehumanisasi atau kelenyapan sifat kemanusiaan dari seni pewayangan yang pada gilirannya akan menurunkan derajat seniman dari kedudukannya yang tinggi sebagai pencipta dan hanya menjadi homo ludens, yaitu seorang pemain belaka. Maka pada era modernisasi sekarang ini diperlukan seniman dalang dan musisi yang konstruktif. Artinya, seniman yang mampu menjawab tuntutan dan kebutuhan penonton lewat karyakarya pedalangan yang etis dan estetis. Dengan demikian sajian pakelirannya diharapkan dapat memotivasi timbulnya pengalaman estetis yang memuaskan serta berperan dalam membangun bangsanya lewat pesan-pesan yang berisi nilai-nilai. Karya seni yang dihasilkan bukan merupakan komoditi pasar dan tidak dangkal tetapi mengutamakan nilai keindahan yang pada gilirannya akan mengangkat harkat dan martabat manusia.

\section{Dalang dan Masyarakat}

Dalang adalah orang yang bertindak sebagai pemain wayang, dan ia mempunyai kedudukan yang sentral dalam pertunjukan wayang kulit. Dalang bertanggung jawab dalam seluruh pergelaran wayang, sebagai metter en scene atau pemimpin musik, sutradara, penyaji, pemimpin artistik serta membuat hidupnya pertunjukan wayang, juru penerang, juru pendidik, penghibur, pendorong dan inovator.

Berhasil dan tidaknya suatu pergelaran wayang sangat tergantung pada kemampuan seniman dalang. Oleh karena itu seorang dalang dituntut tidak hanya menguasai teknis pedalangan saja, namun juga harus memahami bidang yang lain, seperti masalah korohanian, falsafah hidup, pendidikan, kebatinan, kesusasteraan, ketatanegaraan, politik, dan sebagainya. Pada era globalisasi, seorang dalang dituntut memiliki kreativitas yang tinggi karena modernisasi membawa dampak terhadap kehidupan seni pertunjukan wayang, baik dampak yang positif maupun yang negatif. Oleh karena itu setiap sajian wayang hendaknya mempunyai relevansi dengan kehidupan, serta mencerminkan nilai-nilai luhur dan dapat mengangkat harkat dan martabat manusia. Hal ini ditekankan oleh karena seorang dalang menempati posisi yang strategis dalam masyarakat, baik yang menyangkut status sosial maupun aspek ekonomi. Dalam pertunjukan wayang seorang dalang dapat bertindak sebagai: komunikator, dinamisator, inovator, fasilitator, dan emansipator.

Paling tidak ada tiga fungsi sosial yang harus dilakukan oleh dalang yaitu: (1) sebagai komunikator, artinya dalam pertunjukan wayang, dalang punya tugas untuk menyampaikan pesanpesan pembangunan lewat garapan pakelirannya, serta pesan tersebut diolah ke dalam bahasa pedalangan. Misalnya pesan tentang lingkungan hidup, keluarga berencana, diolah dengan bahasa pedalangan dan ditempatkan pada adegan tertentu atau empan-papan seperti pada adegan perang ampyak atau gara-gara; (2) sebagai inovator, artinya dalam menyajikan pakeliran seorang dalang harus dapat menempatkan diri pada suatu posisi yang tidak memihak kepada salah satu norma tertentu. Dalam hal ini karya-karya pedalangan yang dihasilkan harus berorientasi ke masa depan, dan karya seni yang ditampilkan ada relevansinya dengan zaman sekarang, serta dapat menjadi motivasi terjadinya proses perubahan sosial; (3) sebagai emansipator, artinya seniman dalang dapat membantu mengantarkan para penonton secara kelompok atau individu ke tingkat perkembangan kepribadian yang lebih tinggi, dengan cara peningkatan daya apresiatif seni, kepekaan rasa keindahan, yang pada gilirannya akan memperluas persepsi dan memperkaya pengalaman jiwa para penonton.

Suatu pertunjukan wayang kulit, sajiannya diharapkan sebagai motivasi bagi timbulnya pengalaman estetis yang memuaskan, disamping tujuan-tujuan yang lain seperti penerangan, pendidikan, propaganda, politik, hiburan dan sebagainya. Dewasa ini banyak seniman dalang pada sajian wayang sering dibebani berbagai titipan dari para penguasa, namun demikian titipan-titipan itu hendaknya tidak menggeser tugas pokok seorang dalang yaitu meyampaikan isi lakon wayang. Suatu sajian wayang kulit yang bermutu, selalu bermaksud menyampaikan suatu pesan kepada penonton, apakah pesan itu bersifat estetis, moral, spiritual, politis, gagasan pikiran, keagamaan dan sebagainya. Pesan yang disampaikan dalam pakeliran bukan rumusan ilmiah, melainkan marupakan pesan yang menghimbau yang dapat mempengaruhi perilaku 
manusia. Oleh karena itu seorang dalang harus memiliki keterampilan teknis serta kemampuan yang lain, agar hasil kegiatannya mengekspresikan nilaikeindahan. Rasa,imaginasimaupun kreativitas saja tidak cukup, tetapi harus dibekali kemampuan dasar dalam hal: janturan, ginem, pocapan, banyol, pathetan, sendhon, ada-ada, tembang, dhodhogan, gendhing, keprakan, cepengan,tancepan, entasentasan, bedholan, sabetan, repertoar lakon dan sebagainya. Disamping itu seorang dalang juga dituntut memiliki pengetahuan pedalangan, yang menyangkut teknis pakeliran maupun pengetahuan yang menunjang pakeliran wayang dan diharapkan seorang dalang dapat mengolah atau menggarap isi lakon lewat unsur-unsur pakeliran menjadi satu kesatuan yang utuh dan manunggal, sehingga komponen-komponen pakeliran tampak adanya suatu keutuhan.

Bagi seorang dalang sejati, sajian wayang yang ditampilkan akan selalu berusaha menyampaikan pesan kepada penonton. Pesan-pesan itu menyangkut nilai religius, moral, kemanusiaan, patriotisme, keadilan, kesetiaan, kesetiakawanan sosial, yang semuaya disampaikan lewat garapan tokoh yang ditampilkan. Dengan demikian seorang dalang juga dituntut kepekaan terhadap masalah sosial, karena seorang dalang pada hakikatnya adalah makhluk sosial dan manusia etis. Hanya manusialah yang dapat menghayati norma-norma dan nilai-nilai dalam hidupnya, sehingga ia dapat memilih mana tingkah laku yang bersifat susila dan tidak, maka seorang dalang sejati tentu akan berusaha semaksimal mungkin untuk menyajikan karya pedalangannya yang etis-estetis pula.

Jazuli (2003:331-332) membedakan dalang menjadi tiga tipe ideologis yaitu dalang berideologi konservatif, progresif, dan pragmatis. Tipe dalang yang berideologi konservatif, adalah mereka yang cara berpikirnya masih berorientasi masa lampau dan mempunyai tujuan melestarikan status quo serta memitoskan pertunjukan wayang yang penuh dengan nilai tuntunan. Orientasi dalang lebih mengarah pada motif sosial dari pada motif ekonomi. Bentuk pertunjukannya cenderung mengutamakan nilai-nilai kemanusiaan, memberikan pengalaman jiwa serta hiburan yang bermanfaat bagi kehidupan manusia. Tipe dalang berideologi progresif, adalah mereka yang berorientasi dan berwawasan masa kini dan masa depan. Mereka dalam berkarya pedalangan mengadakan pembaharuan atau perubahan guna memunculkan nilai-nilai baru dan menyesuaikan tuntutan zaman. Karya pakelirannya bersifat rekontruksi, reaktualisasi maupun radikal, serta misi pertunjukannya mencari keseimbangan antara tontonan dan tuntunan. Dalang yang bertipe pragmatis, adalah mereka yang orientasi berpikirnya mengarah pada masa kini, dan bertujuan untuk memperoleh keuntungan, kemanfaatan, dan profit komersial. Bentuk pertunjukan wayangnya dimodifikasi sesuai tuntutan pasar, sehingga berkesan kurang memiliki prinsip yang kuat serta lebih mengutamakan porsi hiburan.

Berdasarkan pengamatan di lapangan dewasa ini paling tidak terdapat tiga tipe dalang yaitu: (1) dalang sebagai seniman komoditi atau pasaran; (2) dalang sebagai seniman konstruktif; dan (3) dalang sebagai seniman pembebas. Dalang sebagai seniman komoditi adalah mereka yang dalam berkarya pakeliran selalu mempertimbangkan bagaimana pemasarannya, dan karya pedalangannya dipandang sebagai barang komoditi. Dalang seperti ini mudah terperosok ke dalam karya-karya estetisisme, artinya karyanya tidak etis, cabul, murahan. Dalang sebagai seniman konstruktif, adalah dalang yang mau menjawab tuntutan dan kebutuhan manusia lewat karya seninya yang etis. Ia berperan positif dalam membangun bangsanya lewat pesan-pesan yang berupa nilai-nilai. Karya pedalangannya tidak dangkal dan bukan konvensi pasaran, bukan destroyer dan utopis. Dalang sebagai seniman pembebas berpedoman bahwa hakikat seni adalah kebebasan dan imajinasi seniman adalah bebas. Karya yang dihasilkan menganut prinsip kebebasan yang bertanggung jawab dan menurut mereka bahwa dalam pembangunan bangsa, seniman berperan sebagai barometer kebebasan suatu bangsa.

Seorang dalang dalam sajian wayang kulit, hendaknya tidak hanya menekankan pada halhal yang teknis belaka, tetapi isi lakon hendaknya mendapat porsi garapan yang mantap. Isi lakon yang dimaksud dalam pakeliran, adalah menyangkut nilai kehidupan, entah itu nilai religius atau nilai moral, nilai kemanusiaan dan sebagainya. Tugas seorang dalang yang sedang menyajikan wayang kaitannya dengan kehidupan manusia, merupakan wahana yang ampuh dalam menyebarkan ide-ide atau gagasan baru maupun 
penyampaian nilai-nilai. Sehubungan dengan itu ada dua aspek yang perlu diperhatikan oleh dalang, yaitu konteks estetika atau penyajiannya yang mencakup bentuk dan keahlian yang melahirkan gaya, dan kedua konteks makna yang mencakup pesan dan nilai nilai simboliknya. Orang menghayati pakeliran wayang tidak mungkin tanpa memperhatikan bentuk ujud pakeliran dan gayanya, begitu pula tidak mungkin orang melihat pertunjukan wayang tanpa memperhatikan pesan-pesan yang terkandung secara simbolis, disamping kegiatan pertunjukan wayang itu sendiri merupakan perwujudan fungsionalisasi dari subsistem kebudayaan.

\section{Pengembangan Pertunjukan Wayang}

Semenjak Orde Baru, berbagai teknologi komunikasi modern merambah ke segala aspek kehidupan termasuk dalam kesenian/pertunjukan. Untukmerespon perkembangan IPTEKyang begitu pesat dalam penggarapan atau pengembangan seni pertunjukan wayang perlu memperhatikan tiga hal yaitu: (1) konsep estetis yang matang; (2) teknik kesenian; dan (3) golongan sosial.

Konsep estetis yang matang. Bahwa pertunjukan wayang kulit purwa Jawa yang deselenggarakan di tengah-tengah masyarakat dengan lama waktu tujuh jam atau semalam pada umumnya masih digunakan konsep estetika pedalangan Jawa yakni bersifat simbolis, kontemplatif dan filosofis. Oleh karena itu dalam pengembangan wayang diperlukan konsep estetis yang matang.

Teknik kesenian. Dalam jagad pedalangan terjadi perubahan pendukung yang semula wayang didukung oleh masyarakat yang agrarismistik/rural berubah didukung oleh masyarakat urban atau didukung oleh masyarakat transisi ke industri/maju. Setiap pertunjukan wayang diperlukan teknik yang canggih, rumit, dan banyak referensi. Artinya teknik kesenian tidak membodohkan masyarakat. Teknik kesenian yang maju diperlukan pemikiran yang matang, fantasi yang hidup, perasaan yang kaya, dan intuisi yang tajam. Oleh karena itu masyarakat yang bersifat kota melihat pertunjukan wayang adalah sebagai seni sekuler atau sebagai lakon yang modern, atau sebagai tontonan.

Golongan sosial. Bahwa pertunjukan wayang sebagai pranata sosial masyarakat mendukung kehidupan wayang. Setiap kesenian termasuk seni pedalangan tentu ada pendukung, pembina dan penggerak.

Menurut Brandon (1967) seni pertunjukan teater, termasuk wayang, didukung oleh tiga kelompok yaitu: (a) government support; (b) commercialsupport; dan (c) communal support. Pada zaman kerajaan Surakarta Paku Buwana IX sampai Paku Buwana X (1893 - 1939) seni pedalangan mendapat dukungan pembinaan dari raja. Hal itu dapat dicermati adanya kegiatan pedalangan pada hari wiyosan raja, hari jumenengan, dan tuguran dan hari yang telah ditentukan dengan menampilkan dalang abdi dalem maupun dalang sentana seperti Danuningrat, Cakraningrat, Prabuwinata yang bertindak sebagai penyaji pakeliran. Seiring dengan perubahan sosial yang terjadi di masyarakat, maka semenjak Indonesia merdeka sampai sekarang pertunjukan wayang selalu didukung oleh masyarakat (communal support). Artinya masyarakatlah yang menghidupi/ menanggap wayang untuk berbagai kepentingan seperti peristiwa perkawinan, ulang tahun, supitan, ruwatan, bersih desa dan sebagainya.

Pada waktu kehidupan seni pedalangan didukung oleh penguasa/raja (goverment support) terbentuk tradisi pedalangan gaya keraton yang dikukuhkan adanya pendidikan dalang seperti Padhasuka di Surakarta dan Habhirandha di Yogyakarta. Adanya kegiatan artistik estetik dalam pakeliran maka dihasilkan konsep-konsep keindahan seperti: greget, sem, nges, udanegara, nuksma, langgut, micara, nyawiji, ora mingkuh dan sebagainya yang dewasa ini masih diacu oleh para dalang. Sedangkan pakeliran wayang yang didukung oleh masyarakat melahirkan tradisi pedalangan kerakyatan. Adanya kedua tradisi pedalangan, oleh karena pengaruh masyarakat pendukung seni pewayangan.

Menurut Arnold Hauser (1974), seni merupakan produk masyarakat, maka pandangan masyarakat tertentu akan mempengaruhi wujud seni yang dihasilkan oleh masyarakat itu. Seiring dengan perubahan yang terjadi di tengah masyarakat pendukung budaya Jawa maka dunia pakeliran wayang kulit purwa Jawa mengalami perubahan baik dari teknik pertunjukannya maupun tanggapan penonton terhadap pakeliran wayang. Hal ini terjadi karena wayang merupakan bagian dari kebudayaan tidak luput dari pengaruh kebudayaan modern dan tidak jarang bentuk- 
bentuk kesenian termasuk wayang diciptakan untuk kebutuhan praktis dan mengikuti selera pasar serta kurang memperhatikan nilai estetik.

Fenomena yang terjadi dalam jagad pakeliran sekarang mengisyaratkan adanya pergeseran cara pandang masyarakat baik para dalang maupun penonton dalam menyikapi pertunjukan wayang. Pergeseran pertunjukan wayang menyebabkan terjadinya kekaburan nilai-nilai. Nilai-nilai lama telah ditinggalkan, sedangkan nilai-nilai baru belum mantap fungsinya bahkan belum ditemukan. Hal itu tercermin dalam hampir setiap pertunjukan wayang kulit purwa Jawa masa kini. Permasalahan yang muncul berdasarkan pengamatan di lapangan menunjukkan bahwa sajian pakeliran dewasa ini ada kecenderungan makin berkembang menjadi bentuk-bentuk hiburan sebagai komoditi komersial.

Mencermati permasalahan dunia pedalangan seperti yang disampaikan di muka, teori Raymon Williams (Johnson, 1987) dapat membantu menjelaskan. Menurut Williams, dalam suatu perjalanan sejarah selalu terdapat tiga kekuatan kebudayaan (kultural), yaitu :(a) kekuatan budaya yang dominan; (b) kekuatan budaya yang residual; (c) kekuatan budaya yang bangkit. Tiga kekuatan ini selalu tarik menarik dan tawar menawar dan saling terlibat terus menerus. Ketiga kekuatan kebudayaan ini kiranya dapat digunakan untuk mencermati pertunjukan wayang kulit semenjak tahun 1960 sampai sekarang. Beberapa kekuatan dan otoritas yang mempengaruhi kehidupan seni pedalangan menurut Kayam (2001) adalah otoritas istana atau keraton, otoritas lembaga lembaga pendidikan formal pedalangan, otoritas tradisi lokal para dalang, otoritas para dalang populer atau dalang laku, otoritas penguasa orde yang sedang berkuasa.

Semua otoritas di atas masing-masing memiliki orientasi kesenian atau filosofis dan fungsi seni pedalangan di tengah masyarakat yang berlainan. Pertunjukan wayang dalam otoritas keraton adalah termasuk kekuatan kebudayaan yang residual merupakan sisa-sisa kekuatan masa lampau yang terdapat di Keraton Surakarta dan Keraton Yogyakarta. Pertunjukan wayang gaya keraton yang ditampilkan menganut konsep estetika pedalangan Jawa yang bersifat simbolis, filosofis dan kontemplatif, yaitu bahwa pertunjukan wayang selain kegiatan artistikestetik, juga sebagai ajang olah batin dan kegiatan mistik. Maka pada zaman itu lakon - lakon wayang yang bertema lakon lebet seperti Dewa Ruci, Bima Suci, Sena Lodra, Mintaraga sering ditampilkan dan digemari para pendukung pewayangan, maka wayang dianggap sebagai tuntunan. Pendidikan Formal dalang Konservatori Karawitan Indonesia Surakarta, ISI Surakarta, dan ISI Yogyakarta memandang bahwa pertunjukan wayang sebagai aktivitas artistik - estetik perlu digarap dan diolah. Dalam konteks ini wayang berperan sebagai tontonan atau seni pertunjukan.

Otoritas lembaga-lembaga pendidikan formal pedalangan berada pada semua posisi budaya dominan, residual dan bangkit atau mengambang. Otoritas tradisi lokal para dalang berada pada posisi residual dan bangkit dan memahami bahwa pertunjukan wayang memiliki kekuatan magis yang dapat digunakan untuk menyertai berbagai ritual seperti ruwatan, sadranan, bersih desa dsb. Hal itu hingga sekarang pertunjukan wayang masih dikaitkan dengan peristiwa ritual desa seperti bersih desa yang mengambil cerita Sri Mulih, upacara sadranan dengan mengambil cerita Bratayuda, upacara sedhekah laut mengambil cerita Semar mBangun Kayangan, upacara ruwatan mengambil cerita Kala Takon Bapa dan sebagainya, maka wayang berperan sebagai tatanan. Otoritas dalang populer menempatkan pertunjukan wayang sebagai hiburan yang merespon masyarakat karena mereka memerlukan hiburan. Otoritas penguasa merupakan kekuatan kultural yang dominan dan memandang pertunjukan wayang sebagai tuntunan, tontonan dan tatanan. Namun kenyataan di lapangan menjadi lain yaitu bahwa pertunjukan wayang dijadikan ajang alat propaganda atau kampanye untuk kepentingan tertentu. Oleh karena penguasa sebagai kekuatan kebudayaan dominan memiliki modal ekonomi yang tidak dimiliki oleh otoritas residual sehingga makna tuntunan, tontonan dan tatanan dapat bergeser dan diplesetkan dengan makna lain.

Pertunjukan wayang kulit yang disajikan di tengah-tengah masyarakat pada umumnya cenderung berada pada otoritas para dalang laku dan otoritas para penguasa. Disadari bahwa seni pertunjukan wayang memiliki dua lingkungan yaitu lingkungan material dan lingkungan 
ideologis. Hal itu juga dikatakan oleh M.M. Bakhtin (1986) bahwa lingkungan karya seni dapat dibedakan menjadi dua: yaitu lingkungan material dan lingkungan ideologis. Lebih lanjut dikatakan bahwa karya seni di mediasi oleh hubungan yang erat antara karya seni dengan lingkungan ideologisnya.

Sejalan dengan pemikiran Bakhtin bahwa seni pertunjukan wayang di Jawa semenjak orde Lama - Orde Baru - Orde Reformasi terdapat relasi yang erat dengan kepentingan penguasa untuk menyampaikan ideologi tertentu atau pesan-pesan tertentu. Maka tidak mengherankan bahwa akhir-akhir ini banyak para penguasa atau politikus tampil seolah-olah sebagai seniman untuk memperoleh popularitas, misalnya menjadi pemain ketoprak, penyanyi, dalang, pembaca puisi. Mereka para politikus ingin mencari ketenaran atau popularitas seperti seniman, ketenaran dan popularitas sangat diperlukan bagi para penguasa atau politikus. Sebaliknya seniman dewasa ini juga berlagak sebagai politikus/penguasa. Para seniman pelawak, penyanyi, pemain sinetron dan dalang mendaftarkan caleg atau maju dalam Pilkada.

Howard S.Becker (1982) membagi seniman menjadi empat yaitu: (1) integrated artist; (2) maverick artist; (3) folk artist; dan (4) naive artist. Integrated artist artinya seniman (dalang) yang dapat menyesuaikan perkembangan zaman dan tuntutan masyarakat tanpa mengabaikan kaidahkaidah dalam pedalangan. Maverick artist artinya seniman (dalang) yang masih menghormati pakem dan tradisi oral yang diwarisi dari generasi sebelumnya. Folk artist artinya seniman (dalang) yang kegiatan artistiknya berdasarkan tradisi lokal atau tradisi kerakyatan yang masih mewarnai pertunjukannya. Naive artist adalah orang yang berlagak sebagai seniman yang sebenarnya bukan profesinya sebagai seniman. Misalnya gubernur, bupati, anggota DPR, tampil sebagai dalang, penyanyi, penari $\mathrm{dsb}$.

Dalam dunia pertunjukan wayang kulit purwa Jawa dikenal penggolongan bentuk penyajian wayang sebagai berikut. (a) Wayangan daleman yaitu bentuk pertunjukan wayang yang mengutamakan nilai estetik dan berpijak pada kaidah-kaidah pedalangan; (b) Wayangan pendhapan, yaitu bentuk pertunjukan wayang yang mengakomodasi keinginan penonton namun kaidah-kaidah pedalangannya tidak dikorbankan; dan (c) Wayangan kebonan, yaitu bentuk pertunjukan wayang yang lebih menekankan pada kepentingan hedonistik serta berorientasi pada uang dan kurang intelek.

\section{Penutup}

Bentuk-bentuk pakeliran dewasa ini dikemas sedemikian rupa untuk kepentingan massa. Fenomena semacam ini oleh J. Maquet (1971) disebut sebagai art of acculturation atau art by metamorphosis atau pseudo traditional art. Art of acculturation, artinya pertunjukan wayang yang dikemas untuk massa yang harus menyesuaikan dengan selera penonton yang telah mengalami perubahan bentuk, maka juga disebut art by metamorphosis, karena pertunjukan wayang merupakan akulturasi antara selera estetis dalangnya dengan selera estetis penonton/penikmat. Pseudo-traditional-art apabila diamati dari segi bentuk pertunjukannya masih mengacu pada bentuk-bentuk pakeliran tradisi, tetapi nilai-nilai yang terkandung di dalamnya, atau esensi lakon yang disajikan yang berbentuk sakral, magis dan simbolis atau artistik, kultural, moral-religius, tampak semu atau bahkan sudah ditinggalkan. Berdasarkan temuan di lapangan bahwa pertunjukan wayang kulit purwa masa kini yang berlangsung di tengah-tengah masyarakat pada umumnya berbentuk wayangan pendhapan yang dipadu dengan wayangan kebonan.

Berdasarkan uraian tersebut di atas dapat dikatakan bahwa seni pedalangan dapat mempengaruhi masyarakat dan sebaliknya. Bentuk pakeliran wayang dipengaruhi perubahanperubahan yang terjadi di dalam masyarakat. Pertunjukan wayang dewasa ini mengantisipasi perubahan sosial, sementara ikut berubah sejalan dengan perubahan yang terjadi di masyarakat. Seni Pedalangan dan masyarakat tidak berkaitan secara monolistis, tapi masing-masing dapat ditampilkan sebagai objek dan subjek. Dengan demikian dalam masyarakat transisi atau masyarakat maju, pengaruh sosial dan seni pedalangan bersifat timbal balik. Pakeliran wayang mengungkap kecenderungan-kecenderungan sosial, sementara masyarakat memperlihatkan jejek-jejak pengaruh terhadap perkembangan seni pedalangan. 


\section{Kepustakaan}

Bakhtin, Medve. 1986. The Formal Method in Literary Scholarship. London: Havard Univ. Press.

Becker, A.L. 1979. "Text-Building, Epistemologi, and Aesthetic in Javanese Shadow Theatre," in A.L. Becker and Aram A. Yengoyan (eds.). The Imagination and Reality: Essays on Southeast Asian Coherence System. Norwood, New Jersey: Ablex Publication.

Brandon, J. 1967. Theatre in Southeast Asia. Cambridge: Havard Univ. Press. Boskoff, Alvin.1970. "Recent Theories of Social Change" dalam Warner J. Brandon, James R.1970. On Thrones of Gold Three Javanese Shadow Plays. Cambrigde, Massachusetts: Harvard University Press.

Hauser, Arnold. 1974. The Sociology of Art ( terj. Kenneth J.N) Chicago: University of Chicago Press.

Howard, S. Becker.1982. Art World. Los Angeles: Univ. California Press.

Jazuli, M. 2003. Dalang Negara Masyarakat: Sosiologi Pedalangan. Semarang: Limpad.
Johnson, L. 1987. "Raymond Williams: A MarxistView of Culture " dalam Diane J (ed), Creating Culture: Profile in the Study of Culture. Sydney: Allan and Unwin P.L.

Kayam, Umar. 1981. Seni Tradisi dan Masyarakat. Jakarta: Gramedia. PSK UGM.

2001. Kelir Tanpa Batas. Yogyakarta:

Maquet, J. 1971. Introduction to Aesthetic Anthropology. Massachusetts: Addison W.

Tomars, Adolph S. 1964. "Class System and the Arts", dalam Werner J. Cahman dan Alvin Boskoff (Eds.). Sociology and History: Theory and Research. London: The Free Press of Glencoe.

\section{Sumber Audio}

Soedarsono, Manteb., lakon Wisangeni Kridha (pita kaset), koleksi pribadi.

Rahmadi, Tristuti., lakon Parikesit Jumeneng Ratu (pita kaset), koleksi pribadi.

Soeroto, Anom., Petruk Gembol (pita kaset), koleksi pribadi. 